\title{
ANALYSIS AND SYNTHESIS OF MOS TRANSLINEAR CIRCUITS
}




\title{
ANALYSIS AND SYNTHESIS OF MOS TRANSLINEAR CIRCUITS
}

\author{
by \\ Remco J. Wiegerink \\ MESA Research Institute \\ University of Twente
}

Foreword by

Evert Seevinck

SPRINGER SCIENCE+BUSINESS MEDIA, LLC 


\title{
THE KLUWER INTERNATIONAL SERIES IN ENGINEERING AND COMPUTER SCIENCE
}

\author{
ANALOG CIRCUITS AND SIGNAL PROCESSING \\ Consulting Editor \\ Mohammed Ismail \\ Ohio State University
}

Related Titles:

COMPUTER-AIDED DESIGN OF ANALOG CIRCUITS AND SYSTEMS, L. Richard Carley, Ronald S. Gyurcsik ISBN: $0-7923-9351-1$

HIGH-PERFORMANCE CMOS CONTINUOUS-TIME FILTERS, José Silva-Martínez, Michiel Steyaer, Willy Sansen

ISBN: $0-7923-9339-2$

SYMBOLIC ANALYSIS OF ANALOG CIRCUITS: Techniques and Applications, Lawrence P. Huelsman, Georges G. E. Gielen

ISBN: $0-7923-9324-4$

DESIGN OF LOW-VOLTAGE BIPOLAR OPERATIONAL AMPLIFIERS, M. Jeroen Fonderie, Johan H. Huijsing

ISBN: 0-7923-9317-1

STATISTICAL MODELING FOR COMPUTER-AIDED DESIGN OF MOS VLSI CIRCUITS,

Christopher Michael, Mohammed Ismail ISBN: 0-7923-9299-X

SELECTIVE LINEAR-PHASE SWITCHED-CAPACITOR AND DIGITAL FILTERS, Hussein Baher

ISBN: $0-7923-9298-1$

ANALOG CMOS FILTERS FOR VERY HIGH FREQUENCIES, Bram Nauta ISBN: $0-7923-9272-8$

ANALOG VLSI NEURAL NETWORKS. Yoshiyasu Takefuji

ISBN: $0-7923-9273-6$

ANALOG VLSI IMPLEMENTATION OF NEURAL NETWORKS, Carver A. Mead, Mohammed Ismail

ISBN: $0-7923-9049-7$

AN INTRODUCTION TO ANALOG VLSI DESIGN AUTOMATION, Mohammed Ismail, José Franca

ISBN: $0-7923-9071-7$

INTRODUCTION TO THE DESIGN OF TRANSCONDUCTOR-CAPACITOR FILTERS, Jaime Kardontchik ISBN: $0-7923-9195-0$

VLSI DESIGN OF NEURAL NETWORKS. Ulrich Ramacher, Ulrich Ruckert ISBN: $0-7923-9127-6$

LOW-NOISE WIDE-BAND AMPLIFIERS IN BIPOLAR AND CMOS TECHNOLOGIES, Z. Y Chang, Willy Sansen

ISBN: $0-7923-9096-2$

ANALOG INTEGRATED CIRCUITS FOR COMMUNICATIONS: Principles, Simulation and Design, Donald O. Pederson, Kartikeya Mayaram

ISBN: $0-7923-9089-X$

SYMBOLIC ANALYSIS FOR AUTOMATED DESIGN OF ANALOG INTEGRATED CIRCUITS, Georges Gielen, Willy Sansen ISBN: $0-7923-9161-6$ 
To Cisca

and my parents 


\section{Library of Congress Cataloging-in-Publication Data}

Wiegerink, Remco J., 1964-

Analysis and synthesis of MOS translinear circuits / by Remco J. Wiegerink ; foreword by Evert Seevinck.

p. cm. - (The Kluwer international series in engineering and computer science. Analog circuits and signal processing)

Includes bibliographical references and index.

ISBN 978-1-4613-6411-5 ISBN 978-1-4615-3214-9 (eBook)

DOI 10.1007/978-1-4615-3214-9

1. Integrated circuits. 2. Metal oxide semiconductors.

I. Title. II. Series.

TK7874.W54 1993

621.3815--dc20

93-26664

CIP

Copyright ${ }^{\circ} 1993$ by Springer Science+Business Media New York

Originally published by Kluwer Academic Publishers in 1993

Softcover reprint of the hardcover 1st edition 1993

All rights reserved. No part of this publication may be reproduced, stored in a retrieval system or transmitted in any form or by any means, mechanical, photo-copying, recording, or otherwise, without the prior written permission of the publisher, Springer Science+Business Media, LLC.

Printed on acid-free paper. 


\section{Contents}

Foreword

Acknowledgments $\quad$ xiii

Chapter 1 Introduction 1

1.1 Motivation 1

1.2 Previous work 3

1.3 Outline of this book 4

1.4 References 5

Chapter 2 The MOS Translinear Principle 9

2.1 Introduction 9

2.2 Derivation of the MTL Principle 9

2.3 Using both N-type and P-type transistors in a single
translinear loop

$\begin{array}{lll}2.4 & \text { Second-order effects } & 14\end{array}$

$\begin{array}{ll}\text { A. The body-effect } & 14\end{array}$

$\begin{array}{ll}\text { B. Mobility reduction } & 17\end{array}$

$\begin{array}{ll}\text { C. Weak inversion } & 20\end{array}$

D. Channel length modulation $\quad 21$

E. Component mismatches $\quad 22$

F. Errors caused by parasitic resistance and capacitance 22

$\begin{array}{ll}\text { G. Temperature dependence } & 24\end{array}$

2.5 The effect of noise $\quad 25$

2.6 Dynamic range and distortion $\quad 26$

2.7 Comparing MOS translinear and bipolar translinear circuits 27

2.8 Conclusions 28

2.9 References $\quad 28$ 
Chapter 3 Analysis of MOS Translinear Circuits

3.1 Introduction 31

$\begin{array}{lll}3.2 & \text { TL-graphs } & 32\end{array}$

3.3 Systematic analysis of MOS translinear networks 35

3.4 Example: rail to rail CMOS input stage with a constant $\begin{array}{ll}\text { transconductance } & 40\end{array}$

$\begin{array}{lll}3.5 & \text { Example: vector sum circuit } & 48\end{array}$

3.6 MTL loops that can be electronically opened 54

3.7 MTL networks consisting of a single translinear loop of four transistors $\quad 56$

3.8 Simple graphical representation of MTL networks consisting of a single loop and having one input and one output signal 64

3.9 Development of the computer program MTLPLOT for computer aided analysis of MTL networks

3.10 Comparing the loop equations of MOS and bipolar translinear loops

3.11 Conclusions $\quad 75$

3.12 References $\quad 75$

Chapter 4 Synthesis of MOS Translinear Circuits: A Design Strategy

$\begin{array}{lll}4.1 & \text { Introduction } & 77\end{array}$

4.2 Basic functions realized by MTL circuits $\quad 78$

4.3 Realization of a function using a suitable combination of basic functions

4.4 Example: wideband linear current attenuator with electronically variable gain

4.5 Computer aided synthesis of MOS translinear loops

4.6 Example: class AB rail-to-rail output stage for CMOS operational amplifiers

4.7 Conclusions $\quad 93$

$\begin{array}{lll}4.8 & \text { References } & 94\end{array}$ 
Chapter 5 Comparison of MOS Translinear Loop Topologies

$\begin{array}{lll}5.1 \text { Introduction } & 97\end{array}$

5.2 Choosing a suitable loop topology 98

$\begin{array}{lll}5.3 & \text { The stacked loop topology } & 100\end{array}$

$\begin{array}{lll}5.4 & \text { The up-down loop topology } & 102\end{array}$

5.5 The electronically simulated loop topology 104

$\begin{array}{lll}5.4 \text { Conclusions } & 108\end{array}$

$\begin{array}{lll}5.5 & \text { References } & 108\end{array}$

Chapter 6 Application: Fast Four-Quadrant Current Multiplier 109

$\begin{array}{lll}6.1 & \text { Introduction } & 109\end{array}$

6.2 Principle of operation 110

$\begin{array}{lll}\text { 6.3 An MTL current squaring circuit } & 110\end{array}$

6.4 The four-quadrant current multiplier 113

$\begin{array}{lll}6.5 & \text { Second-order effects } & 114\end{array}$

$\begin{array}{ll}\text { 6.6 Simulated and measured results } & 120\end{array}$

$\begin{array}{lll}6.7 & \text { Conclusions } & 123\end{array}$

$\begin{array}{lll}6.8 & \text { References } & 123\end{array}$

Chapter 7 Application: Variable-Gamma Circuit for Colour Television

$\begin{array}{lll}7.1 \text { Introduction } & 125\end{array}$

$\begin{array}{lll}7.2 & \text { The variable gamma system } & 125\end{array}$

$\begin{array}{lll}7.3 & \text { The variable gamma function block } & 129\end{array}$

7.4 Computer aided implementation of the inverse hyperbolic $\begin{array}{ll}\text { sine function } & 130\end{array}$

$\begin{array}{lll}7.5 & \text { Simulated and measured results } & 134\end{array}$

$\begin{array}{lll}7.6 & \text { Conclusions } & 138\end{array}$

$\begin{array}{lll}7.7 & \text { References } & 140\end{array}$ 
Chapter 8 Conclusions

8.1 Introduction 141

$\begin{array}{lll}8.2 \text { Summary } & 141\end{array}$

8.3 Original contributions of this book 143

8.4 Recommendations for further research 143

Appendix A: TL graphs of MTL networks with one or two loops and less than 8 transistors 145

Appendix B: MOS translinear loops with 7 or less transistors 147

Appendix C: Some MTL network realizations 150

$\begin{array}{lr}\text { Index } & 155\end{array}$ 


\section{Foreword}

This book has its roots in an idea first formulated by Barrie Gilbert in 1975. He showed how bipolar analog circuits can realize nonlinear and computational functions. This extended the analog art from linear to nonlinear applications, hence the name translinear circuits. Not only did this new principle enable marvellous signal processing functions to be accurately implemented, but also the circuits were simple and practical. The perennial problems of analog IC design, namely temperature sensitivity, processing spread, device nonlinearity and paracitic capacitance were solved to a large extent.

Using the translinear principle in circuit design requires changing your point of view in two ways. First, the grossly nonlinear characteristic of transistors is viewed as an asset rather than as a harmful property. Second, no longer are the signals represented by voltages, but by currents. In fact, the attendant voltage changes are distorted but, as they are very small, they are only of secondary interest.

Understanding and analyzing a given translinear circuit is fairly straightforward. But what about the converse situation: suppose you're given some nonlinear or computational function to implement? How to find a suitable translinear circuit realization? The general problem of analog circuit synthesis is a difficult one and is receiving much attention nowadays. Some years ago, I had the opportunity to investigate methods for designing bipolar translinear circuits. It turned out that translinear networks have some unique topological properties. Using these properties it was possible to establish heuristic synthesis procedures.

In this book, Wiegerink extends translinear circuit design to MOS-technology. The square-law characteristic of MOS transistors operated in the saturated region is exploited. This results in nonlinear signal-processing functions different from those provided by bipolar translinear circuits which are based on the exponential current-voltage characteristic. Also different is the quality of function implementation. Bipolar circuits maintain precision over a larger dynamic range. However, this is offset by the fact that MOS-technology is the dominant industry driver. 
The book starts by deriving the MOS translinear principle and investigating the effects of transistor nonidealities. Next, a systematic approach to analysis is developed based on a graphical method which is easy to visualize. A significant contribution here is a computer-aided analysis program. Probably the most important part of the book concerns circuit synthesis. Design strategies are described which combine the strengths of human creativity, the insight afforded by graphical representation and computer processing power. The techniques are demonstrated by designing various useful circuits: an output stage for CMOS opamps, a four-quadrant multiplier and a variable-gamma circuit for colour television. Finally, a number of new nonlinear building blocks are presented in an appendix.

Evert Seevinck 


\section{Acknowledgments}

This book was originally published as a Ph.D. thesis. It describes the results of a research project carried out at the MESA Research Institute at the University of Twente, Enschede, The Netherlands. I would like to thank Prof. Hans Wallinga, my thesis supervisor, Evert Seevinck, Roel Wassenaar and Rien van Leeuwen for many fruitful discussions and for their comments on the original manuscript. Furthermore, a like to thank Anne-Johan Annema and Eric Klumperink for many helpful discussions.

I would like to thank Prof. Han Huijsing, Jeroen Fonderie, Ruud Eschauzier and Ron Hogervorst from the University of Delft, The Netherlands, for their help in the field of operational amplifiers.

I wish to thank Wim de Haan, Henk ten Pierick, Kees Jaspers and Dick de Greef from Philips Components, Eindhoven, The Netherlands, for presenting the variable-gamma problem to me and for the realization of the chips.

Furthermore, I wish to thank the following students: Jacob Botma, Dick ten Napel, Peter de Jong, Jan van Sinderen, Arjan van de Berg and Guido Jaspers, who all made a significant contribution to the work.

Finally, I thank Carla Weber, Anita Kannegieter, Hans Riesebos, Arjen Wiegerink and Cisca Weber for keeping me from working too hard by accompanying me at trips to London and Paris.

Remco Wiegerink 